\title{
Asia and Europe are Different? : Credit Reponse to Global Bank Deleveraging
}

\author{
Shekhar Aiyar \\ International Monetary Fund, Washington D.C, U. S. A. \\ Sonali Jain-Chandra \\ International Monetary Fund, Washington D.C, U. S. A.
}

\begin{abstract}
During the global financial crisis, European banks sharply contracted foreign claims on recipient economies. This paper examines the impact of that deleveraging on credit supply in recipient economies, with a particular focus on Asia. Identification is achieved by exploiting heterogeneity in the ex-ante patterns of funding reliance on different European banking systems, and in variation in the ratio of local claims in local currency to total foreign claims in recipient economies. These sources of variation are used to create instruments for the deleveraging shock. We find that the contraction of foreign claims in European bank was associated with a substantial reduction in domestic credit supply in a broad sample of countries. However, the credit supply response in Asia was only about half the size of the response in non-Asian countries, possibly due to stronger policy response and healthier local bank balance sheets in the Asian countries at the outset of the crisis.
\end{abstract}

JEL Classifications: G01, G2, E3, E5

Key Words: Global banks, Liquidity shock, Cross-border lending, Instrumental variables

\footnotetext{
* Corresponding Author: Shekhar Aiyar; European Department, International Monetary Fund, 700 19th Street, NW, Washington DC, 20431, U. S. A.; Tel: +1 2026235973, Fax: +1 2025895973, E-mail: saiyar@imf.org.

Co-Author: Saonali Jain-Chandra; Asia and Pacific Department, International Monetary Fund, 700 19th Street, NW, Washington DC, 20431, U. S. A.; Tel: +1 2026235881, Fax: +1 2025895881, E-mail: sjainchandra@imf.org.

Acknowledgements: We are grateful to Roberto Cardarelli and Jerry Schiff for valuable comments and suggestions. Marie Kim provided excellent research assistance.
} 


\section{Introduction}

Global banks played a central role in transmitting the Global Financial Crisis (GFC) across countries, with cross-country banking linkages amplifying the adverse shock. It is well established that as global banks were faced with a severe liquidity shock, they pared their foreign (and domestic) assets down. As Cetorelli and Goldberg (2011) note, while reversals occurred in succession "all broad categories of [capital] inflows, by far the sharpest decline in activity was in international bank loans." During the GFC, as funding markets seized up, both euro area and U.K. banks withdrew sharply from other parts of the world, including from Asia. From peak to trough, the foreign claims of euro area and of U.K. banks in Asia fell by around 37 percent and 21 percent of outstanding claims, respectively (Figure 1).

\section{Figure 1. Consolidated Foreign Claims on Asian Economies}

(In billions of U.S. dollars; on immediate borrower basis)

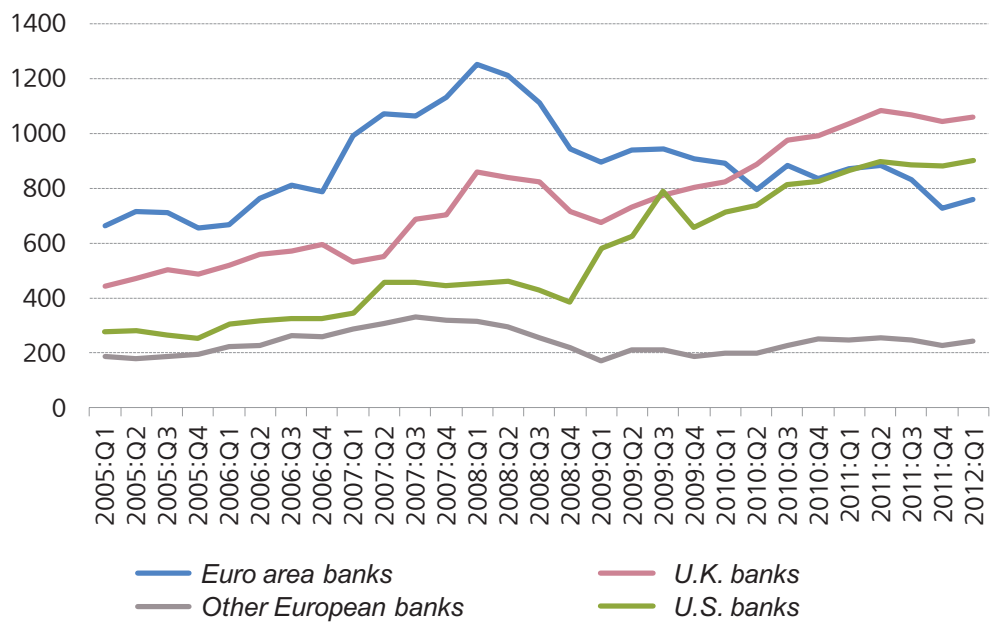

(Source) BIS, Consolidated Banking Statistics (Table 9B)

While a large literature exists on the international transmission of bank liquidity shocks to bank loan supply, a relatively recent literature has emerged focusing specifically on the impact of the external funding shock during the GFC on domestic credit supply in recipient countries. ${ }^{1}$ Cetorelli and Goldberg (2011) examine the multiple channels of transmission of

\footnotetext{
${ }^{1}$ A number of papers provide evidence on the real impact of external shocks to bank liquidity. Peek and Rosengren (1997) show that a shock to Japanese banks' liquidity (arising from falling Japanese equity prices) led to a reduction in their lending into the U.S. economy. Khwaja and Mian (2008) document a fall in loans extended by Pakistani banks, in response to an external funding shock (the imposition of capital controls in the wake of the country's 1998 nuclear tests). Schnabl (2012) finds that the liquidity shock to global banks arising from the Russian default in 1998 led to a pullback in lending to Peruvian banks, and that Peruvian banks responded by
} 
the balance sheet shocks in the advanced country banks to emerging market economies. These potential transmission of an adverse liquidity shock to the parent bank include a reduction in cross-border lending, pull-back of funding to affiliates a reduction in cross-border interbank borrowing, and the ensuing contraction in the lending operations of domestic banks. They find evidence of lending supply effects through all three channels. Aiyar $(2011,2012)$ examines balance sheet evidence for a large sample of U.K. resident banks, both domestically-owned and foreign-owned; tracing the propagation of the funding shock to banks' external liabilities to lending within the United Kingdom. He finds that the contraction in external funding was associated with a substantial contraction in bank lending to the real economy. Moreover, foreign subsidiaries and branches reduced lending more sharply than domestically owned banks. ${ }^{2}$ De Haas and van Horen (2012) provide evidence of the cross-border transmission of the liquidity shock in the syndicated loans market.

This paper contributes to this emerging literature on the transmission to the real economy of the external funding shock to bank balance sheets during the GFC. We focus specifically on Asia, a region of the world that recovered relatively quickly, and assess whether the credit supply response in Asia to deleveraging by foreign banks was different than in other parts of the world. Rather than looking at total foreign bank credit to Asia, we restrict our attention to the linkages between European banks and Asian economies for two reasons. First, European banks play an important role in supplying credit to several Asian economies. If the ongoing euro area crisis were to intensify, these banks could further pare foreign assets down, as described in the IMF’s Spring 2012 Global Financial Stability Report (IMF, 2012), potentially causing a shock to credit supply in Asia. Thus the study of European bank linkages with Asia provides a window into the likely effects of a large bank deleveraging. Second, the econometric analysis has to exclude the United States as a source country, as in late 2008 the surviving large stand-alone investment banks were transformed into bank-holding companies and included for the first time in the Bank for International Settlements (BIS) database on cross-border bank lending. As a result, the U.S. foreign claims series shows a sharp increase in 2008, rendering the data unsuitable for making an inference.

The main questions that we aim to answer are: (i) to what extent did deleveraging by European banks translate into a credit crunch in destination countries; and (ii) was the response of credit supply in Asia different during this period? A priori, a large deleveraging by foreign banks, could affect credit supply in two ways through a reduction in foreign funding for local banks. On the other hand, if local and regional banks stepped up lending in response to foreign banks deleveraging, and if the policy response was sufficiently vigorous, this could mitigate any domestic credit supply response.

\footnotetext{
reducing domestic credit. See Aiyar (2011) for a more detailed literature review.

${ }^{2}$ Such "home bias" in bank lending has been documented in several different contexts (e.g. Gianetti and Laeven (2012), Cetorelli and Goldberg (2008)).
} 


\section{The Role of European Banks in Asia}

Asian liabilities to European banks are substantial, but with considerable variation across economies. Figure 2 shows the consolidated foreign claims of European banks on Asian economies, taken from the BIS consolidated banking statistics database. Consolidated foreign claims include both cross-border credit and credit extended by the local subsidiaries and branches of European banks. ${ }^{3}$ While Asian countries on average rely on European bank funding less than regional comparator like Latin America and emerging Europe, the degree of reliance is highly variable. The financial centers, Hong Kong SAR and Singapore, which play a regional intermediating role, have much higher liabilities to European banks than do other regions of the world, with the exception of emerging Europe. Among other Asian countries, Australia, New Zealand, Malaysia, Korea and Taiwan Province of China are the largest borrowers from European banks, while China, India, and most ASEAN countries generally have smaller liabilities (Figure 2).

The regional pattern is broadly similar if European bank foreign claims are scaled by domestic credit to the private sector rather than GDP. However, the liabilities of countries with deep banking systems like Australia and New Zealand are somewhat reduced by this measure, while those of some ASEAN countries, like Indonesia and the Philippines, are higher.

\footnotetext{
${ }^{3}$ The BIS's consolidated banking database reports data on a banking group basis, with the source country identified as the country where the banking group is headquartered. It differs from the BIS locational banking database, which identifies the source country as the country where the individual bank is resident. Consider, for example, a claim by a U.K.-headquartered bank resident in Hong Kong on Thailand. In the consolidated database this is reported as a U.K. claim on Thailand, whereas in the locational database it is reported as a Hong Kong claim on Thailand.
} 
Figure 2. Consolidated Foreign Claims of European Banks on Asia

(Unit: percent of GDP; as of 2012 Q1)

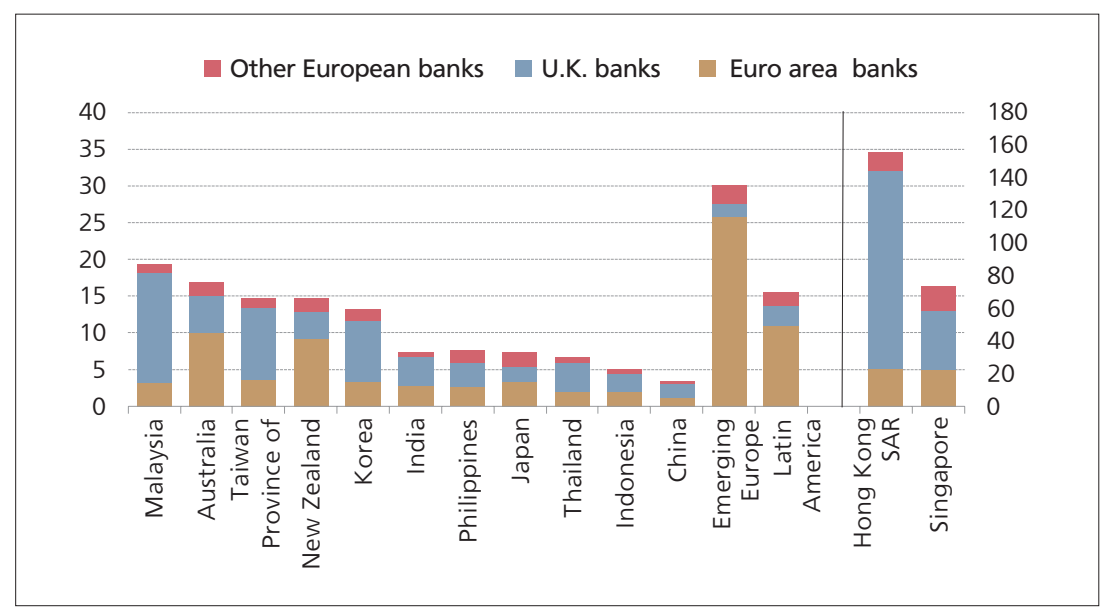

(Note) Claims are on ultimate risk basis. Sum of quarterly GDP in U.S. dollar between 2011 Q2 and 2012 Q1 in the denominator.

(Source) Bank for International Settlements (BIS); CEIC Data Company Ltd.;

Haver Analytics; and IMF staff calculations.

Figure 3. BIS Reporting Banks' Foreign Claims on Asian Economies by Sector

(Unit: percent of GDP; as of 2012 Q1)

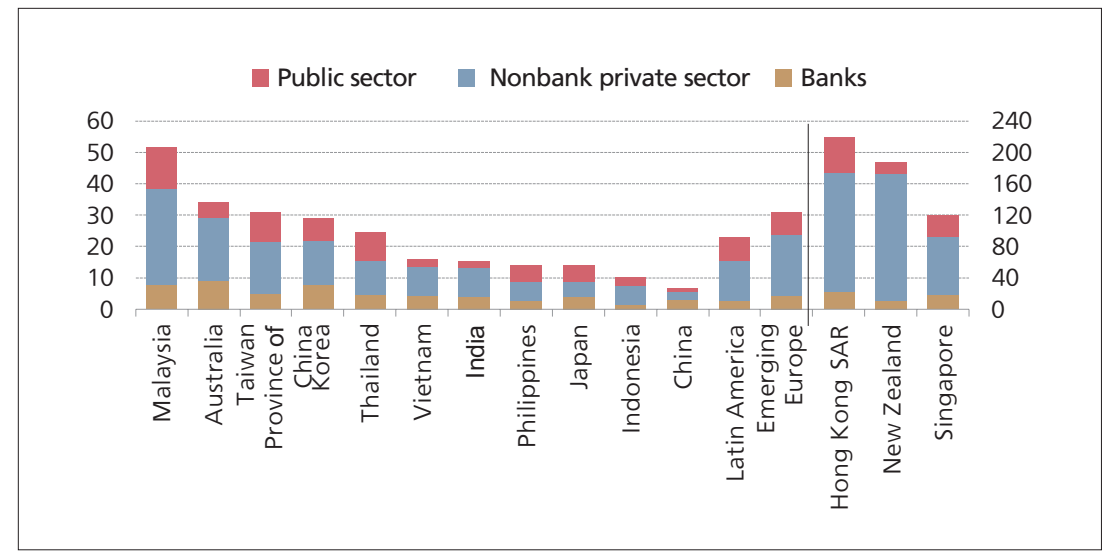

(Note) Claims are on ultimate risk basis. Sum of quarterly GDP in U.S. dollar between 2011 Q2 and 2012 Q1 in the denominator.

(Source) Bank for International Settlements (BIS); CEIC Data Company Ltd.;

Haver Analytics; and IMF staff calculations. 
Among European banks, U.K. banks have a particularly significant presence in the region, accounting for a larger share of foreign funding than in Latin America or Emerging Europe. Anecdotal evidence suggests that they may ordinarily view deleveraging by euro area banks as an opportunity to increase market share in Asia, but that this does not necessarily hold when there is a widespread banking crisis. During the GFC, which was characterized by severe stresses in global interbank and other funding markets, U.K. banks joined other European banks in retrenching foreign assets from the region.

A decomposition of European bank credit to recipient economies by sector is not available in the publically available BIS database. Figure 3 shows a sectoral decomposition by recipient country for the foreign claims of all BIS-reporting banks not just European banks. For most economies in the region, the nonbank private sector - businesses and households - is the main recipient of foreign credit. Anecdotally, trade credit is an important part of lending to businesses, and European banks are particularly active in this area. Furthermore, European banks tend to specialize in complex project financing, which may not be easy to substitute quickly with other sources of credit.

In several Asian economies, lending by local subsidiaries and branches is a substantial part of overall European bank claims, and to the extent that these claims are funded by local deposits, they are less vulnerable to deleveraging pressures emanating from European countries. One indicator of relative sensitivity to external liquidity shocks is the ratio of international claims to foreign claims within a recipient country. In fact, we shall exploit this fact in our identification strategy. International claims, as reported by the BIS, refer to the sum of cross-border claims and local claims in foreign currency. Foreign claims include international claims and local claims in local currency. As noted in the previous section, international claims, which are much less likely to be backed by local deposits, tend to be more volatile than local claims in local currency, which are often funded by local deposits. Hence the greater the ex ante ratio of international claims to foreign claims, the more susceptible a country is to deleveraging when external funding pressures emerge. Figure 4 shows the ratio of international claims to foreign claims for several Asian economies: a lower ratio implies ex ante lower vulnerability to foreign bank deleveraging. In comparison to other regions of the world, the ratio is quite large, but again, with considerable intra-regional heterogeneity. 
Figure 4. Consolidated International Claims of European Banks

(Unit: percent of foreign claims; as of 2012 Q1)

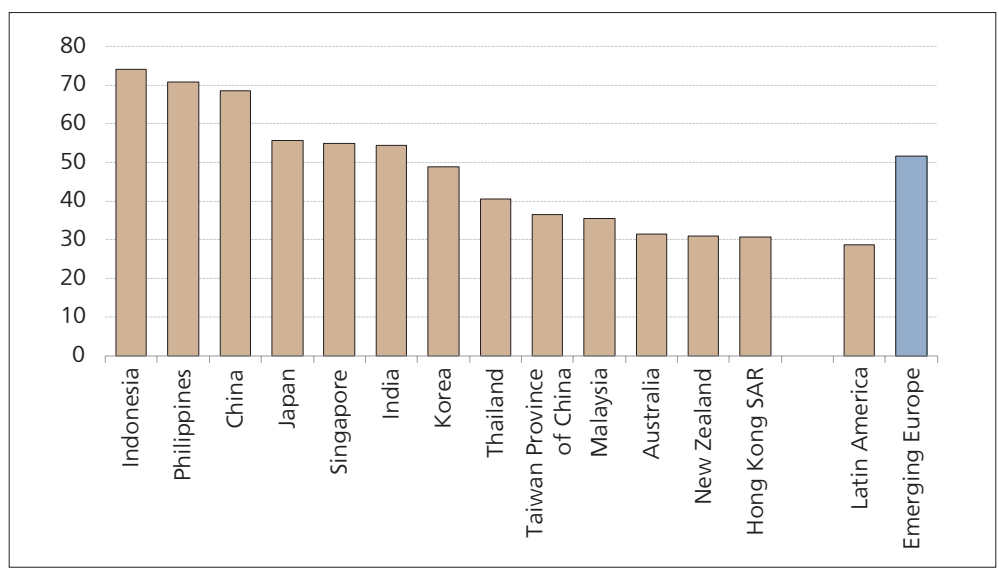

(Note) Claims are on immediate borrower basis.

(Source) Bank for International Settlements (BIS); IMF staff calculations.

\section{Econometric Methodology}

The econometric analysis focuses on estimating the response of domestic credit supply in recipient countries to deleveraging by European banks. As discussed in the introduction, the reason for focusing on European banks is that, given the continuing crisis in the euro area, a potential sharp deleveraging shock is most likely to come from European banks. Also, while the United States is another important source country, the U.S. foreign claims from the Bank of International Settlements (BIS) has a serious structural break. For the purpose of this study, the shock period refers to 2008 Q1 2009 Q1, where 2008 Q1 is the peak of outstanding foreign claims in most economies, and 2009 Q1 the trough.

Following Aiyar (2011) and Schnabl (2012), the empirical framework relies on a differencein-differences specification, which exploits the cross-sectional heterogeneity in the dataset. We estimate:

$$
\Delta G R_{-} D C_{i}=\alpha+\beta \Delta G R_{-} F C_{i}+\varepsilon_{i}
$$

$\triangle G R_{-} F C_{i}$, the main explanatory variable is the change in foreign claims by European banks to the recipient country $i$. The dependent variable, $\triangle G R_{-} D C_{i}$, is the change in the growth rate of domestic credit in the recipient country $i$. Both variables are specified as differences in growth rates between the pre-crisis and crisis period. Data are gathered for a sample of 
75 emerging economies and non-European advanced economies. ${ }^{4}$

The empirical approach must confront a number of potential issues, including endogeneity and disentangling loan-demand effects. The relationship between domestic credit and foreign banking flows can in principle run in both directions. Reduced foreign inflows can lead to a decline in domestic credit, but it is also possible that anemic activity may attract fewer inflows. To circumvent this potential endogeneity, the analysis instruments the main explanatory variable using two different instruments: (i) the pre-crisis ratio of international claims to foreign claims, with a higher ratio implying greater ex ante vulnerability to deleveraging, and (ii) the weighted sum of the proportionate deleveraging by European source countries during the crisis period, where the weights represent the importance of a given source country to the recipient country in question.

To be precise, the first instrument can be denoted as:

$$
\mathrm{Z}_{1 i}=\frac{I C_{i}}{F C_{i}}
$$

where $I C_{i}$ is average international claims by European banks on country $i$ over the four quarters preceding the shock period; and $F C_{i}$ is average foreign claims by European banks on country $i$ over the same period.

The second instrument is:

$$
\mathrm{Z}_{2 i}=\sum_{j=1}^{J}\left[\frac{F C_{i j}}{\sum_{j}^{J} F C_{i j}}\left\{\Delta \sum_{t=1}^{I} F C_{i j}\right\}\right]
$$

The first term in this expression, the "weight" $\frac{F C_{i j}}{\sum_{j}^{\prime} F C_{i j}}$, is simply a measure of the ex ante importance of source country $j$ to recipient economy $i$; it shows the fraction of foreign funding for country $i$ coming from country $j$ on average over the four quarters preceding the crisis period. The second term, $\Delta\left(\sum_{i=1}^{I} F C_{i j}\right)$, measures the amount of deleveraging undertaken by source country j's banks with respect to all recipient countries during the crisis period. The idea is that if a recipient country is ex ante highly dependent for funding on source countries that deleveraged by a large amount in aggregate during the shock, then that should be a good predictor of a large funding shock for the recipient economy. Conversely, if a recipient economy is ex ante highly dependent for funding on a source countries that did not deleverage much during the shock, then that should be a good predictor of a relatively limited funding shock for the recipi-

\footnotetext{
${ }^{4}$ The sample is constructed from a union of sets of emerging markets compiled by (i) the FTSE Group; (ii) MSCI; (iii) Standard \& Poor's; (iv) Dow Jones; (v) Frontier Strategy Group; (vi) Banco Bilbao Vizcaya Argentina (BBVA) Research; and (vii) The Emerging Markets Index. In addition, the following recipient advanced economies are included: Australia, Canada, Japan, and New Zealand.
} 
ent economy.

These instruments are expected to be strongly correlated with actual deleveraging, but should not have a direct impact on the main variable of interest, that is, the change in domestic credit during the shock period. One concern about the validity of the second instrument is that during the 2008 crisis, all source countries were deleveraging at the same time in the context of the global liquidity shock. If the proportionate deleveraging by source countries were too similar, then the proposed instrument would be weak. But in fact an examination of the retrenchment by European source countries shows considerable variation. This implies that from a recipient country's perspective, the identity of the precise source countries on which it is reliant for funding should be a good ex ante predictor of the shock that it faces.

The second concern relates to the fact that, an observed decline in domestic credit can be driven by reduced demand or supply. During the 2008 crisis, demand for credit also fell as activity slowed, so it is possible that the observed decline in credit was demand driven. To control for demand, we include the ex ante share of exports to GDP. Two related features of the crisis make this variable a good instrument: (i) the decline in demand in most recipient economies was driven, in the first instance, by a contraction in external demand; and (ii) the decline in external demand in most recipient countries was large relative to the decline in domestic demand. The second specification including demand effects has the following form:

$$
\Delta G R_{-} D C_{i}=\alpha+\beta_{1} \Delta G R_{-} F C_{i}+\beta_{2} X_{i}+\varepsilon_{i}
$$

Next, the analysis tackles the question whether Asia's response was different. Two modifications are made to the above specification in the form of a dummy variable for Asia to capture any level effect, and an interaction between the Asia dummy and the change in foreign claims to capture any differences in the slope coefficients.

$$
\Delta G R \_D C_{i}=\alpha+\beta_{1} \Delta G R \_F C_{i}+\beta_{2} X_{i}+\beta_{3} A s i a+\beta_{4}\left(\Delta G R \_F C_{i} * A s i a\right)+\varepsilon_{i}
$$

The data utilized for the regressions in the baseline consist of differences in the stock of foreign claims at two points in time. As such, the data do not account for changes in exchange rates during this turbulent period. In the absence of foreign claims, BIS data disaggregated by currency database do not allow us to precisely account for all bilateral valuation changes. Nonetheless, it is possible to improve upon the methodology above, which amounts to assuming that all foreign claims are denominated in U.S. dollars.

Accordingly, we exploit the fact that foreign claims data are disaggregated into international claims (cross-border claims and local claims in foreign currency), and local claims in local currency. We assume that all cross-border claims and local claims in foreign currency of European 
banks in Asia are denominated in the US dollars. So, we convert the local claims in local currency at the prevailing bilateral exchange rate against the U.S. dollar. This yields a currencyadjusted flow series which we use to check the robustness of our estimates from the unadjusted change-in-stocks data.

\section{Results}

The main finding is that deleveraging by European banks for the year of 2008 led to a large contraction in credit supply in destination countries. Table 1 shows the results from two-stage least squares regressions. In the most elementary specification of column (1), a reduction in foreign claims of 1 percent resulted in a 0.54 percent decline in domestic credit in the broad sample of recipient countries. In column (2) we control for demand effects, and domestic credit remains equally sensitive to the changes in foreign liabilities. Post-estimation statistics provide validity of our identification strategy: the Kleibergen-Papp rank Wald test rejects underidentification, while Sargan J-statistic cannot reject the null hypothesis that the instruments are uncorrelated with the error terms in the structural equation. ${ }^{6}$

Asian countries' credit supply response to deleveraging by European banks was significantly less than that of other countries. Column (3) introduces an Asia dummy variable, both by itself and as an interaction term. The Asia intercept is not significant, but the interaction with the change in foreign liabilities does seem important. In column (4), the Asia intercept is thus omitted. This column shows that credit supply in Asian countries contracted by about 0.36 percent in response to a 1 percent European deleveraging leading to Asian response size about half of non-Asian response.

\footnotetext{
${ }^{5}$ This is not an unreasonable assumption. McGuire and von Peter (2009) document that for United Kingdom and Swiss banks, U.S. dollar assets account for the majority of foreign claims. For German, Spanish, French, Dutch and Belgian banks foreign claims in euros are greater than foreign claims in the US dollars, but this likely reflects intra-European lending, whereas lending outside Europe is dominated by the US dollar claims. Anecdotal evidence is consistent with these stylized facts.

${ }^{6}$ The results are robust to controls for the importance of European bank credit in each economy, using variables such as the ratio of European bank claims to total domestic credit, or the ratio of European bank claims to GDP. Moreover, the results are broadly consistent with the larger literature on the cross-border transmission of liquidity shocks, for example, Cetorelli and Goldberg (2011), Aiyar (2011), and Schnabl (2012).
} 
Table 1. Impact of change in foreign claims on change in domestic credit supply

\begin{tabular}{|c|c|c|c|c|}
\hline & (1) & $(2)$ & (3) & $(4)$ \\
\hline $\begin{array}{l}\text { Dependent variable: } \\
\text { Change in domestic bank lending }\end{array}$ & 2SLS & $2 S L S$ & $2 S L S$ & 2SLS \\
\hline Change in foreign claims & $\begin{array}{l}0.536 \text { ** } \\
(0.220)\end{array}$ & $\begin{array}{l}0.499 * * \\
(0.213)\end{array}$ & $\begin{array}{l}0.771 \text { ** } \\
(0.338)\end{array}$ & $\begin{array}{l}0.73^{* * \star} \\
(0.215)\end{array}$ \\
\hline Exports-to-GDP (preshock) & & $\begin{array}{l}-0.058 \\
(0.051)\end{array}$ & $\begin{array}{l}-0.085 \\
(0.055)\end{array}$ & $\begin{array}{l}-0.117^{* *} \\
(0.054)\end{array}$ \\
\hline Asia & & & $\begin{array}{l}-0.234 \\
(0.174)\end{array}$ & \\
\hline Asia $\times$ Change in foreign claims & & & $\begin{array}{l}-0.684 \text { * } \\
(0.358)\end{array}$ & $\begin{array}{l}-0.363^{* * *} \\
(0.115)\end{array}$ \\
\hline Constant & $\begin{array}{r}-0.035 \\
(0.109)\end{array}$ & $\begin{array}{r}-0.032 \\
(0.113)\end{array}$ & $\begin{array}{r}0.072 \\
(0.171)\end{array}$ & $\begin{array}{r}0.049 \\
(0.110)\end{array}$ \\
\hline Number of observations & 76 & 76 & 76 & 76 \\
\hline \multicolumn{5}{|l|}{$\begin{array}{l}\text { Under - identification } \\
\left(\mathrm{H}_{0}: \text { Not identified) }\right.\end{array}$} \\
\hline Kleibergen-Papp rank & 13.67 & 14.71 & 8.56 & 11.474 \\
\hline $\begin{array}{l}\text { Langrange multiplier Wald } \\
p \text {-value }\end{array}$ & 0.001 & 0.001 & 0.014 & 0.0032 \\
\hline \multicolumn{5}{|c|}{$\begin{array}{l}\text { Over -identifying restrictions } \\
\left(\mathrm{H}_{0} \text { : Instruments uncorrelated with error process) }\right.\end{array}$} \\
\hline Sargan chi-square statistic & 5.32 & 6.56 & 4.075 & 0.99 \\
\hline$p$-value & 0.21 & 0.11 & 0.44 & 0.319 \\
\hline
\end{tabular}

(Note) Robust standard errors in parentheses. Statistical significance at 1, 5, and 10 percent levels is denoted by $* * *, * *$, and *

(Source) IMF staff estimates

Table 2 shows the results from the robustness check using exchange rate adjusted claims data. The coefficient on the foreign liabilities is slightly larger in specifications 1 and 2 relative to Table 1. Similar to the previous set of regressions, the elasticity for Asia is lower, at just under half of the response from non-Asian economies. The similarity of Tables 1 and 2 increases our confidence that the results are not overly contaminated by valuation effects. 
Table 2. Impact of change in foreign claims on change in domestic credit supply (using exchange rate adjusted foreign claims data)

\begin{tabular}{|c|c|c|c|c|}
\hline & (1) & $(2)$ & (3) & $(4)$ \\
\hline $\begin{array}{l}\text { Dependent variable: } \\
\text { Change in domestic bank lending }\end{array}$ & $2 S L S$ & 2SLS & $2 S L S$ & $2 S L S$ \\
\hline Change in foreign claims & $\begin{array}{l}0.587^{* * *} \\
(0.214)\end{array}$ & $\begin{array}{l}0.564^{* * *} \\
(0.209)\end{array}$ & $\begin{array}{l}0.8399^{* *} \\
(0.332)\end{array}$ & $\begin{array}{l}0.693^{* * *} \\
(0.195)\end{array}$ \\
\hline Exports-to-GDP (preshock) & & $\begin{array}{l}-0.055 \\
(0.049)\end{array}$ & $\begin{array}{l}-0.065 \\
(0.060)\end{array}$ & $\begin{array}{l}-0.098 * \\
(0.054)\end{array}$ \\
\hline Asia & & & $\begin{array}{l}-0.300 \\
(0.188)\end{array}$ & \\
\hline Asia $\times$ Change in foreign claims & & & $\begin{array}{l}-0.739 \text { ** } \\
(0.356)\end{array}$ & $\begin{array}{l}-0.302 \text { *** } \\
(0.111)\end{array}$ \\
\hline Constant & $\begin{array}{r}-0.028 \\
(0.097)\end{array}$ & $\begin{array}{r}-0.019 \\
(0.102)\end{array}$ & $\begin{array}{r}0.081 \\
(0.159)\end{array}$ & $\begin{array}{r}0.01 \\
(0.096)\end{array}$ \\
\hline Number of observations & 76 & 76 & 76 & 76 \\
\hline \multicolumn{5}{|l|}{$\begin{array}{l}\text { Under - identification } \\
\left(\mathrm{H}_{0}: \text { Not identified }\right)\end{array}$} \\
\hline Kleibergen-Papp rank & 12.58 & 13.1 & 8.076 & 12.325 \\
\hline $\begin{array}{l}\text { Langrange multiplier Wald } \\
p \text {-value }\end{array}$ & 0.001 & 0.001 & 0.0176 & 0.0021 \\
\hline \multicolumn{5}{|c|}{$\begin{array}{l}\text { Over -identifying restrictions } \\
\left(\mathrm{H}_{0} \text { : Instruments uncorrelated with error process) }\right.\end{array}$} \\
\hline Sargan chi-square statistic & 3.035 & 3.721 & 2.083 & 0.412 \\
\hline$p$-value & 0.82 & 0.53 & 0.15 & 0.52 \\
\hline
\end{tabular}

(Note) Robust standard errors in parentheses. Statistical significance at 1, 5, and 10 percent levels is denoted by $* * *, * *$, and $*$

(Source) IMF staff estimates

\section{Why did Asia React Differently?}

The results above suggest that the transmission of deleveraging by European banks to local credit supply was more muted in Asia than in the rest of the world. A decline of 1 percent in foreign claims by European banks was associated with a decline in domestic credit about 0.5 0.7 percent in a broad sample of economies, but a decline of only 0.3 0.4 percent for Asian economies. What accounts for this difference? We defer a rigorous examination of this question to future research, but offer a couple of speculative answers here.

The strong policy response mounted by Asian economies could be one reason for the smaller credit supply impact of foreign deleveraging. Data limitations ${ }^{7}$ and nonuniform definitions (of policy rates) make it difficult to econometrically test the role of policy responses in the regression

\footnotetext{
${ }^{7}$ For instance, including fiscal policy variables would limit the sample to about 40 countries.
} 
framework used in this paper. But a nonparametric examination of the sample data does suggests that the monetary, and to a lesser extent the fiscal, policy response in Asia was more vigorous than in other regions over the period studied here (Figure 5). ${ }^{8}$ In addition, Asian countries also took a number of measures to maintain market confidence and to stabilize financial markets. These included instituting liquidity guarantees, negotiating Federal Reserve swap lines, strengthening regional reserve pooling, expanding deposit insurance, guaranteeing non-deposit liabilities, relaxing mark-to-market rules to exercise regulatory for bearance and supporting trade finance and Small and Medium Enterprises (SME) programs (Table 3).

Figure 5. Differences in policy responses: Asia versus Non-Asia

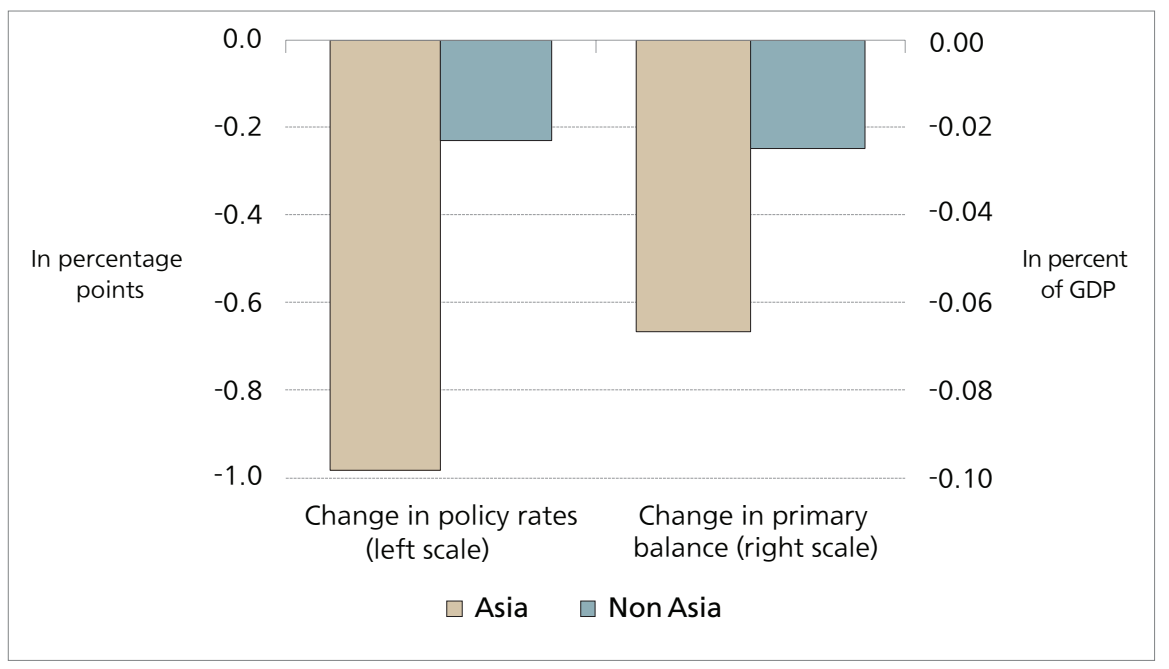

(Note) The chart shows the change in policy rates during the shock period (2008 Q1 2009 Q1) and the change in the primary balance between end-2008 and end- 2007 (as fiscal data are generally available only at an annual frequency). (Source) CEIC Data Company Ltd.; Haver Analytics; and IMF, WEO database and staff calculations.

\footnotetext{
${ }^{8}$ This figure shows the change in policy rates over the crisis period; however, the change in the fiscal balance is shown for the end of 2008 as these data are available only on an annual basis. The magnitudes are not very sizable for two reasons: first, the implementation of fiscal policy entails significant lags and it is likely that while most governments had decided to use fiscal policy, these were not deployed by the end of 2008, and second, the absence of quarterly data means that the timing does not fully align with the crisis period.
} 
Table 3. Summary of policy actions taken in Asia during the global financial crisis

\begin{tabular}{|c|c|c|c|c|c|c|c|c|c|c|c|c|}
\hline & 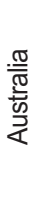 & 兑 & 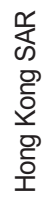 & $\stackrel{\underline{\underline{0}}}{\underline{\underline{\underline{C}}}}$ & 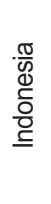 & 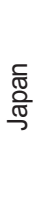 & 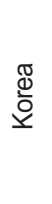 & $\frac{\frac{\pi}{N}}{\frac{\pi}{\pi}} \frac{\sigma^{\frac{\pi}{\pi}}}{\sum}$ & 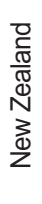 & 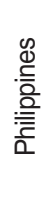 & 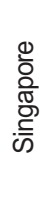 & 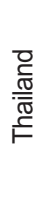 \\
\hline Liquidity assistance in local currency & $\sqrt{ }$ & & $\sqrt{ }$ & $\sqrt{ }$ & $\sqrt{ }$ & $\sqrt{ }$ & $\sqrt{ }$ & & $\sqrt{ }$ & $\sqrt{ }$ & & \\
\hline Lend foreign exchange & $\sqrt{ }$ & & & $\sqrt{ }$ & $\sqrt{ }$ & $\sqrt{ }$ & $\sqrt{ }$ & & $\sqrt{ }$ & $\sqrt{ }$ & $\sqrt{ }$ & \\
\hline Expand deposit insurance & $\sqrt{ }$ & & $\sqrt{ }$ & & $\sqrt{ }$ & & $\sqrt{ }$ & $\sqrt{ }$ & $\sqrt{ }$ & $\sqrt{ }$ & $\sqrt{ }$ & $\sqrt{ }$ \\
\hline Guarantee nondeposit liabilities & $\sqrt{ }$ & & & & & & $\sqrt{ }$ & & $\sqrt{ }$ & & & \\
\hline Prepare bank capital injection & & $\sqrt{ }$ & $\sqrt{ }$ & $\sqrt{ }$ & & $\sqrt{ }$ & $\sqrt{ }$ & & & & & $\sqrt{ }$ \\
\hline Create demand for assets & $\sqrt{ }$ & $\sqrt{ }$ & & $\sqrt{ }$ & $\sqrt{ }$ & $\sqrt{ }$ & $\sqrt{ }$ & $\sqrt{ }$ & & & & \\
\hline Impose short sale restrictions & $\sqrt{ }$ & & $\sqrt{ }$ & & $\sqrt{ }$ & $\sqrt{ }$ & $\sqrt{ }$ & & & & $\sqrt{ }$ & \\
\hline Relax mark-to-market rules & & & & & $\sqrt{ }$ & $\sqrt{ }$ & $\sqrt{ }$ & $\sqrt{ }$ & & & & \\
\hline Institute SME programs & & $\sqrt{ }$ & $\sqrt{ }$ & $\sqrt{ }$ & $\sqrt{ }$ & $\sqrt{ }$ & $\sqrt{ }$ & $\sqrt{ }$ & & $\sqrt{ }$ & $\sqrt{ }$ & $\sqrt{ }$ \\
\hline Support trade finance & $\sqrt{ }$ & $\sqrt{ }$ & $\sqrt{ }$ & $\sqrt{ }$ & $\sqrt{ }$ & & $\sqrt{ }$ & & $\sqrt{ }$ & & & $\sqrt{ }$ \\
\hline Secure Fed swap lines & $\sqrt{ }$ & & & & & $\sqrt{ }$ & $\sqrt{ }$ & & $\sqrt{ }$ & & $\sqrt{ }$ & \\
\hline
\end{tabular}

(Source) Bank for International Settlements, Economist Intelligence Unit (2010), Asmundson and others (2011)

Another reason for more subdued impact of foreign deleveraging could be that Asia's local banking systems had healthier balance sheets at the onset of the crisis. Figure 6 shows leverage ratios - the ratio of debt to equity - for Asian financial firms relative to global peers. ${ }^{9}$ Banking systems in the Advanced Americas and in Advanced Europe were much more leveraged than their counterparts in Advanced Asia-almost three times, in the case of Advanced Europe. This meant that banks in countries such as Australia and Japan did not suffer the same pressure to deleverage like other major international banks when global liquidity dried up in 2008. They could expand credit supply in regional economies in response to deleveraging by other foreign banks. Moreover, the leverage ratio for Emerging Asia was less than half of the comparators in the emerging economies of Latin America. ${ }^{10}$ Balance sheet strength thus provided a buffer to Asian economies during the global financial crisis.

\footnotetext{
${ }^{9}$ The focus is on leverage ratios rather than capital adequacy ratios, since the latter are typically defined in terms of risk-weighted assets, and regulators differ widely in different regions of the world in their definitions of risk weights and permissible regulatory capital (Das and Sy, 2012). Hence comparisons of capital adequacy ratios across broad regions such as Asia, Europe, and the Americas are problematic.

${ }^{10}$ While Emerging Europe had the lowest leverage ratios of all, this does not adequately capture the region's high reliance on direct cross-border credit from highly leveraged West European banks.
} 
Figure 6. Debt-to-Equity ratio in financial firms at end-2007

(Total asset-weighted average)

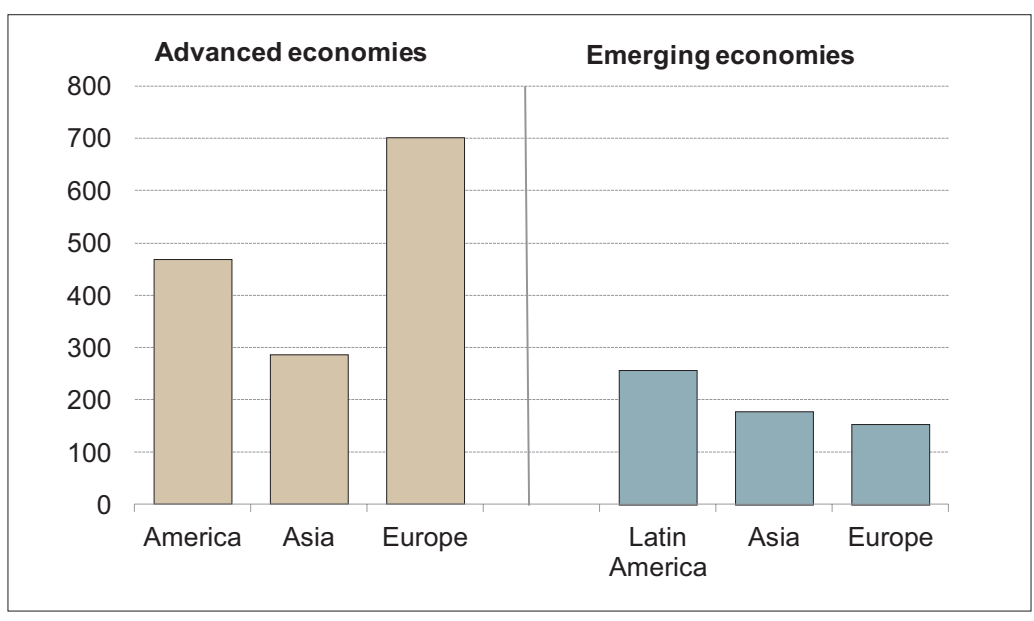

(Source) Thomson Reuters Worldscope; and IMF staff calculations.

The empirical results of this paper suggest that, given similar vigorous policy action and local banking system buffers, Asia could again dampen the adverse effects from a major deleveraging event. The IMF's most recent Regional Economic Outlook for Asia (IMF, 2012b) points out that most Asian countries have room to cut interest rates in the face of a crisis. Fiscal space has shrunk since the global financial crisis, but remains high in most Asian economies by international standards. And Asian bank balance sheets remain strong in general, with low non-performing loans and capital adequacy ratios exceeding regulatory norms indicating that regional banks could take up some of the slack in the event of a large deleveraging by foreign banks. Moreover, as noted in the introduction, Asian reliance on European bank funding was less than in the case of regional comparator such as Latin America and Emerging Europe.

Received 13 December 2012, Revised 3 April 2013, Accepted 2 May 2013

\section{Reference}

Aiyar, S., 2011, "How did the Crisis in International Funding Markets Affect Bank Lending? Balance Sheet Evidence From the UK," Bank of England Working Paper, No. 424.

Aiyar, S., 2012, "From Financial Crisis to Great Recession: The Role of Globalized Banks," American Economic Review, Papers and Proceedings, Vol. 102 (3), pp. 225-30.

Cetorelli, N., and L. Goldberg, 2008, "Banking Globalization and Monetary Transmission," NBER Working Paper, No. 14101. 
Cetorelli, N., and L. Goldberg, 2011, "Global Banks and International Shock Transmission: Evidence from the Crisis,” IMF Economic Review, Vol. 59 (1).

Das, S. and A. N. R. Sy, 2012. "How Risky Are Banks' Risk Weighted Assets? Evidence from the Financial Crisis," IMF Working Papers 12/36 (Washington: International Monetary Fund).

De Haas, R., and N. van Horen, 2012, "International Shock Transmission after the Lehman Brothers Collapse: Evidence from Syndicated Lending," American Economic Review, Papers and Proceedings, Vol. 102 (3), May, pp. 231-37.

Giannetti, M., and L. Laeven, 2012, "The Flight Home Effect: Evidence from the Syndicated Loan Market during Financial Crises," Journal of Financial Economics, Elsevier, Vol. 104 (1), pp. $23-43$.

International Monetary Fund, 2012, Global Financial Stability Report, Spring 2012 (Washington).

Khwaja, A., and A. Mian, 2008, "Tracing the Effect of Bank Liquidity Shocks: Evidence From an Emerging Market,” American Economic Review, Vol. 98 (4).

McGuire, P., and G. von Peter, 2009, “The US Dollar Shortage in Global Banking," BIS Quarterly Review, March.

Peek, J., and E. Rosengren, 1997, "The International Transmission of Financial Shocks: The Case of Japan," American Economic Review, Vol. 87 (4).

Schnabl, P., 2012, "The International Transmission of Bank Liquidity Shocks: Evidence from an Emerging Market," Journal of Finance, forthcoming. 